\title{
DIAMETER DISTRIBUTION OF INDIGENOUS TREES AS INDICATOR OF ADAPTED SPEGIES IN SEMI-ARID RANGELANDS OF KENYA
}

\author{
Mengich EK ${ }^{1, *}$, Macharia JM${ }^{3}$, Mitloehner $\mathbf{R}^{4}$, Too $\mathrm{DK}^{5} \&$ Muturi $\mathbf{G M}^{2}$ \\ ${ }^{1}$ Rift Valley Eco-Region Research Programme, Kenya Forestry Research Institute (KEFRI), PO Box 382-20203, Londiani, Kenya \\ ${ }^{2}$ Kenya Forestry Research Institute Headquarters, PO Box 20412-00200 Nairobi, Kenya \\ ${ }^{3}$ Department of Botany, Egerton University, PO Box 536-20115, Njoro, Kenya \\ ${ }^{4}$ Institute of Silviculture, Georg-August University, Busgenweg 1, D-37077, Goettingen, Germany \\ ${ }^{5}$ Department of Natural Resources, Egerton University, PO Box 536-20115, Njoro, Kenya
}

*emengich3@hotmail.com

Submitted April 2019; accepted November 2019

\begin{abstract}
Diameter distributions of indigenous trees as possible criteria for indicating adapted species in semi-arid rangelands were assessed at Nthangu, Kathonzweni and Kibwezi forests of Makueni County, Kenya using existing vegetation, agro-climatic maps and Landsat images. The sites have mean annual rainfalls of 974, 700 and $616 \mathrm{~mm}$ respectively, and moisture indices of 49, 35 and 32\%. Data on diameters at breast height (DBH) and DBH distributions were collected using transects, 18 sample plots of size $2500 \mathrm{~m}^{2}$ and 90 subplots. Shapiro-Wilk test was used to determine normality of DBH distributions, and $t$-tests were conducted on species occurring in two of the three study sites. Statistically significant differences were declared at $\mathrm{p}<0.05$. Mean DBH values were 7.6, 6.4 and $4.6 \mathrm{~cm}$ at Kibwezi, Kathonzweni and Nthangu respectively. Ecologically important trees with high populations of juvenile individuals and near-perfect inverted J-shaped distributions were Searsia spp., Acacia hockii and Diospyros mespiliformis at Nthangu; Combretum collinum, Combretum apiculatum and Acacia tortilis at Kathonzweni; and A. tortilis, Acacia mellifera and Commiphora africana at Kibwezi. These species were likely candidates for rehabilitation of degraded sections as their DBH distributions indicated regenerating, sustainable and stable populations adapted to the respective sites.
\end{abstract}

Keywords: Diameter at breast height, trees, rehabilitation, semi-arid, rangelands, degraded sites

\section{INTRODUCTION}

Woody vegetation cover in semi-arid rangelands has declined over time due to pressure from increasing human populations and accompanying increases in demand for various tree products and services. The number of trees that can tolerate drought stress have diminished because of other factors such as frequent outbreaks of bushfires (Eckhardt et al. 2000, Gandiwa 2011) and climate change (Ensor \& Berger 2009, Gonzalez et al. 2012), which have resulted in harsher and drier conditions in these areas. These factors have resulted in moderate to severe land degradation and desertification that are manifested in forms of impoverishment, depletion of vegetation cover and deterioration of soils.

In the semi-arid rangelands of Kenya, there have been concerted efforts to reverse the impacts of degradation through tree planting (Kigomo 2003). Planting of appropriate tree species in respective localities is key to successful rehabilitation of these degraded sites (Derbel \& Chaieb 2013). Provenance trials have mostly been used to identify suitable species to plant in these areas. However, the trials have largely tested suitability of fast-growing exotic tree species which are rarely adapted to local conditions (Milimo et al. 1994, Reubens et al. 2011). They also take long to generate information that would in turn guide on appropriate species to plant.

The use of indigenous species for rehabilitation has not been widely practised in Kenya, but the potential for their use is widely acknowledged (Oba et al. 2001, Mulizane et al. 2005). When properly matched with planting sites, indigenous species are easier to establish and have minimal risks of becoming invasive (Anonymous 2010). Nevertheless, rehabilitation using indigenous species in Kenya faces challenges as the country 
lacks guidelines on species-site matching. Published guidelines (KEFRI 1990, Braun et al. 1993) are based on results of years of rangewide reconnaissance surveys that recorded occurrence of species in given localities. Braun et al. (1993) superimposed the results of the reconnaissance surveys on the forest seed zones of Kenya as a further improvement to reduce risk of moving tree seeds far beyond their ecological range. The publications provide general guidelines at a national scope due to the nature of data used in their development. However, rehabilitation programmes for specific sites are still faced with the challenge of correct species choices for prevailing physiognomic characteristics. In this study, we assessed diameters at breast height (DBH) of indigenous trees, calculated mean values, and constructed diameter distribution curves and histograms as possible criteria for indicating adapted species, and as basis for selecting suitable tree species for rehabilitating degraded semi-arid landscapes.

\section{MATERIALS AND METHODS}

\section{Study area}

The study was conducted in Makueni County, Kenya (Figure 1). The county lies between $1^{\circ} 35^{\prime}$ and $2^{\circ} 35^{\prime} \mathrm{S}$, and $37^{\circ} 10^{\prime}$ and $38^{\circ} 30^{\prime} \mathrm{E}$ and covers an area of $7965.8 \mathrm{~km}^{2}$ (Anonymous 1997). It is generally low-lying with altitude ranging between $600 \mathrm{~m}$ at Tsavo and $1900 \mathrm{~m}$ asl on Kilungu hills. A large proportion of the county falls within the semi-humid to arid regions (agroclimatic zones IV-VI) with moisture indices of less than $50 \%$, and low and unreliable annual rainfall ranging from 200 to $900 \mathrm{~mm}$ in the low-lying areas and from 800 to $1200 \mathrm{~mm}$ in the hills (Sombroek et al. 1982, Jaetzold 1983, Anonymous 1997). The rainfall is bimodally distributed and occurs in March/April and November/December. The November/December rains are usually more reliable both in amount and distribution and account for $58 \%$ of the annual total precipitation (Musembi 1986).

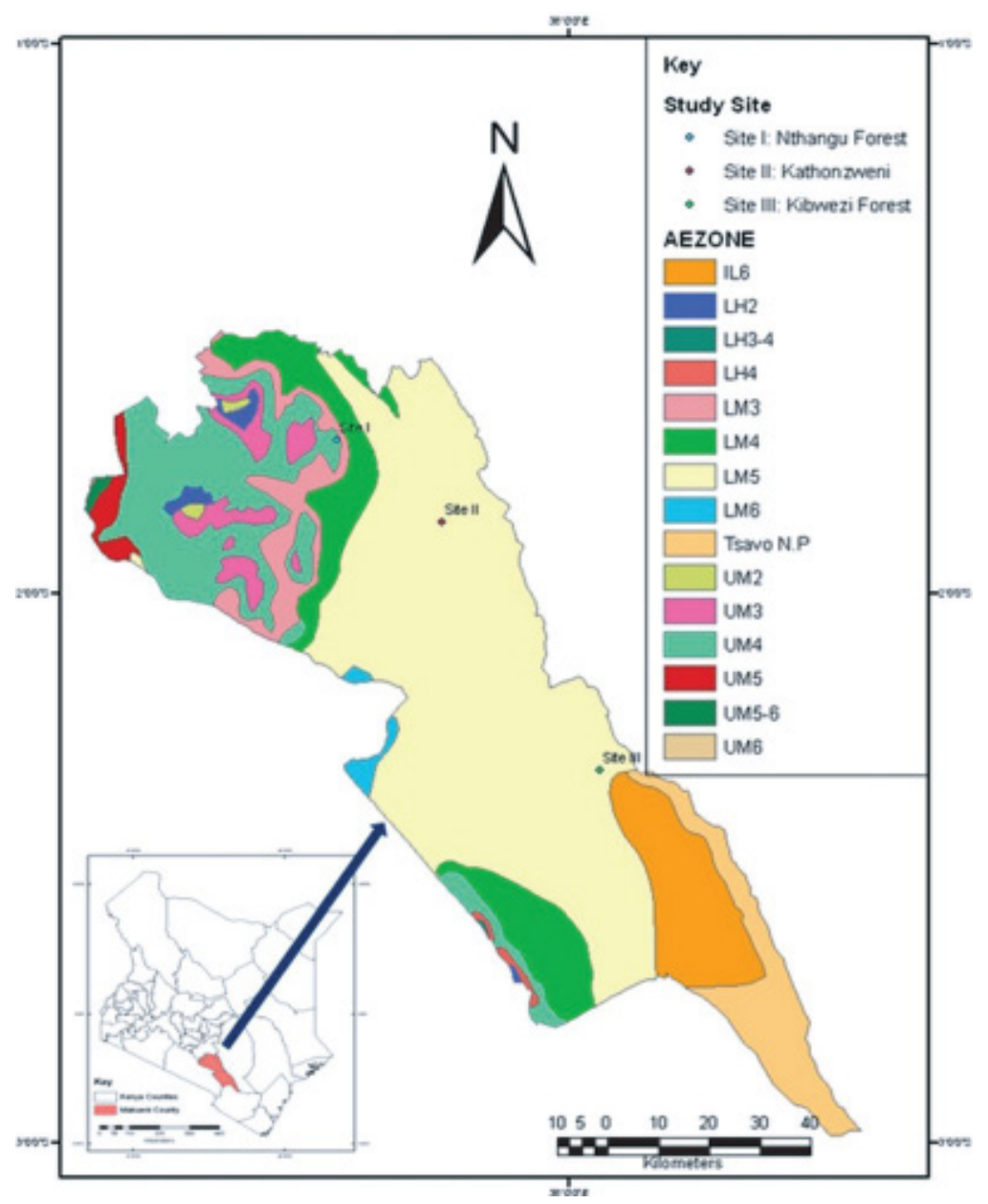

Figure 1 Location and agro-ecological zones of Makueni County, Kenya (Mengich et al. 2013) 
Makueni County has two major agro-ecological zones, namely, upper midland and lower midland. The main zones are based on their probability of meeting the temperature and water requirements of the main leading crops (Table 1). The major agro-ecological zones are further divided into sub-zones depending on humidity levels and water supply (Table 1; Figure 1).

\section{Study sites}

Three study sites were randomly selected, according to agro-ecological zones, using agroclimatic maps and Landsat imageries based on existing vegetation (Lambrecht 1989, Shiver \& Borders 1996, Figure 1). The maps and satellite images were obtained from the Survey of Kenya and the Department of Resource Surveys and Remote Sensing (Anonymous 2006). Selection of sites was complemented by a tour of the county and a survey of the vegetation and local weather facilities.

Selected sites were minimally disturbed natural forests, woodlands and bushlands located in Nthangu (1575 m asl; site I), Kathonzweni (1250 m asl; site II) and Kibwezi (900 m asl; site III). Nthangu forest covers a total area of 2697.8 ha and is made up of six blocks, namely, Nthangu (843.8 ha), Kitondo (1086.4 ha), Kyai (106 ha), Kithendu (218.9 ha), Waiya (263 ha) and Kalimani (179.7 ha). Nthangu forest block lies at $37^{\circ} 37^{\prime} \mathrm{E}, 01^{\circ} 43^{\prime} \mathrm{S}$, with the highest point found at $1575 \mathrm{~m}$ asl. In 1996, part of the forest was clear-felled and planted with plantation tree species that included cypress (Cupressus lusitanica) (124.5 ha), pines (Pinus radiata and P. patula) (447 ha), Eucalyptus spp. (41 ha), and Calitris robusta (14 ha). The forest is managed by Kenya Forest Service and access is restricted.

Study sites in Kathonzweni division were located at Muusini, Mathemba and Miangeni villages of Mavindini location. The sites bordered Kenya Agricultural and Livestock Research Organization (KALRO) Kampi-yaMawe dryland research substation $(\sim 1230 \mathrm{~m}$ asl, $01^{\circ} 57^{\prime} \mathrm{S}, 37^{\circ} 40^{\prime} \mathrm{E}$ ) which receives a mean annual rainfall of between 400 and $500 \mathrm{~mm}$. Miangeni village lies at a lower elevation near Athi River, where environmental conditions were hotter and drier.

Study sites at Kibwezi occupied part of Kibwezi Forest land owned by the University of Nairobi's
Institute of Dryland Research, Development and Utilization. The land is used for research and training. Kibwezi lies at an altitude of about $900 \mathrm{~m}$ asl, and has annual rainfall of about $600 \mathrm{~mm}$ and a mean annual temperature of $27{ }^{\circ} \mathrm{C}$. The south-eastern part of Kibwezi forest forms part of Tsavo National Park and is therefore set aside for wildlife conservation.

As there were no climatic data recording stations within the selected sites, the climatic data used were those of nearby weather stations within the same zone, namely, Katende forest station, KALRO Kampi ya Mawe and Makindu meteorological stations, for the three sites respectively. Mean annual rainfall values for Nthangu, Kathonzweni and Kibwezi were 974, 700 and $616 \mathrm{~mm}$ respectively. Respective moisture indices were 49,35 and $32 \%$.

\section{Establishment of sample plots}

Data were collected based on $50 \mathrm{~m} \times 50 \mathrm{~m}$ $\left(2500 \mathrm{~m}^{2}\right)$ sample plots established $1-3 \mathrm{~km}$ in alternate directions (to the right or left) after every $4-5 \mathrm{~km}$ intervals along the transects. Sample plots were established according to Lambrecht (1989) and Shiver and Borders (1996). At Nthangu, the sample plots were established along a 15-km north-south earth road running from the forester's office to Mitubu hill near Wote town. At Kathonzweni, sample plots were established along a 30-km west-east earth road connecting Kampi ya Mawe and Miangeni near Athi River. At Kibwezi, plots were established along the west-east earth road connecting Kisayani market and Kibwezi River. In sloping areas, sample plots were aligned along the slope. In flat areas, the alignment was random.

\section{Tree species inventory}

All trees in each sample plot were scientifically identified using available literature (Dale \& Greenway 1961, Beentje 1994, Maundu \& Tengnas 2005) and by their local names with assistance of local informants. Trees were counted and recorded by species and DBH. For ease of assessment and to avoid repetition, each sample plot was partitioned into five equal units, and resultant data were aggregated for analysis. Data from trees with DBH below $10 \mathrm{~cm}$ were not recorded. 


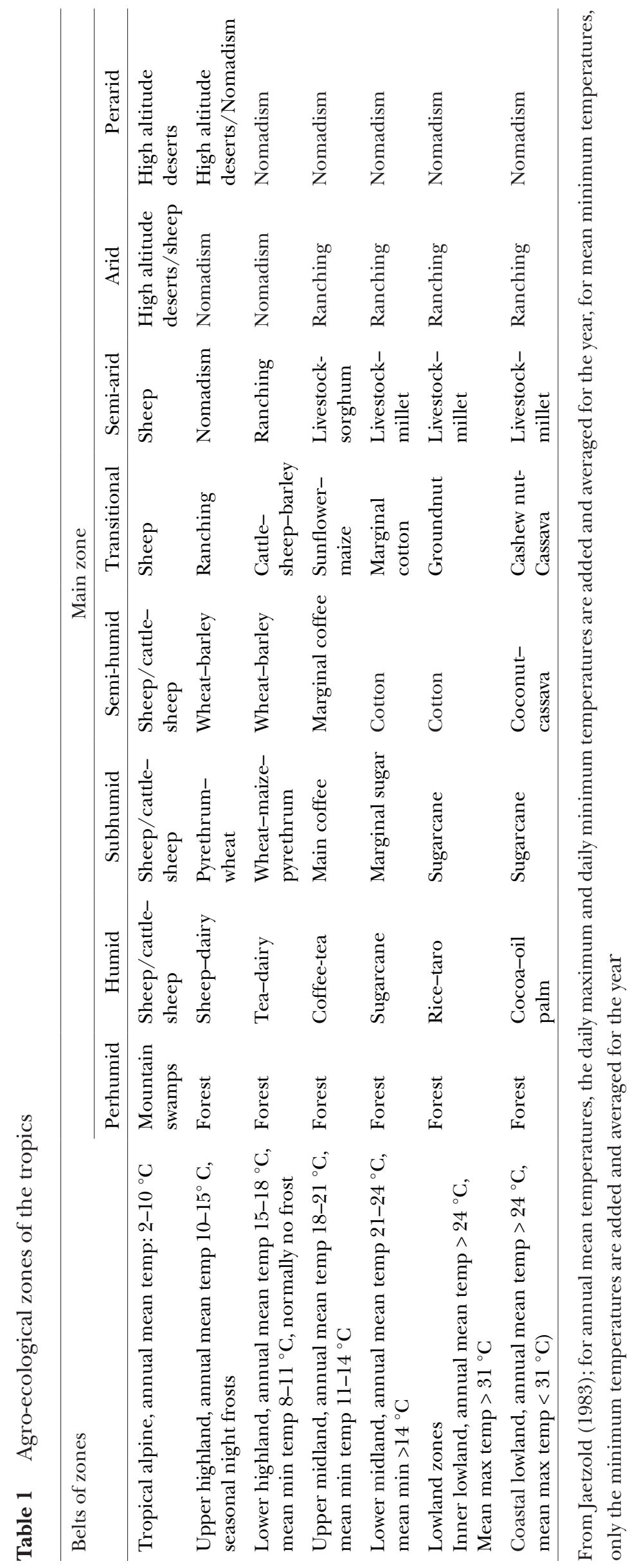




\section{Assessment of DBH}

DBH was measured using diameter tapes. Arithmetic mean diameters (d) of the trees were calculated as follows:

$$
\mathrm{d}=1 / \mathrm{n} \sum_{\mathrm{i}=1}^{\mathrm{n}} \mathrm{d}_{\mathrm{i}}
$$

where $d_{i}=$ diameter of the individual $\left(i^{\text {th }}\right)$ tree and $n=$ total number of trees of the plot.

\section{Determination of important value index}

The important value index (IVI) was derived following Misra (1968):

IVI $=$ relative abundance $(\mathrm{RA})+$ relative dominance $(\mathrm{RD})+$ relative frequency $(\mathrm{RF})$

where, abundance $(\mathrm{A})=$ number of individuals $\mathrm{ha}^{-1}\left(\mathrm{~N} \mathrm{ha} \mathrm{h}^{-1}\right), \mathrm{RA}=$ abundance of a given species/ total abundance of all species $\times 100$, dominance (D) = basal area $\left(\mathrm{m}^{2} \mathrm{ha}^{-1}\right), \mathrm{RD}=$ basal area of a given species/total basal area of all species $\times 100$, frequency $(\mathrm{F})=$ percentage $(\%)$ of plots in which the species is represented, and RF = frequency of a given species/total frequency of all species $\times 100$

\section{Construction of diameter distribution bar graphs}

In order to construct diameter distribution bar graphs, the DBHs were divided into 3-cm classes for both overall distribution and distribution of ecologically important tree species based on their IVIs. For the distribution, each diameter class was plotted against the density (individuals $\mathrm{ha}^{-1}$ ) of species occurring within that class. For species with high DBH values, the higher diameter classes were combined to allow easier construction of the overall distribution curves.

\section{Statistical analysis}

All data were entered into Microsoft Excel Version 2007 where data management techniques such as data checking for errors, explorations and general pattern of the data were performed. Statistical analyses of the data were performed using GenStat v16 and SPSS for Windows 2015 v21. Arithmetic mean DBH values were determined for each of the sites and for individual tree species and diameter distribution bar graphs constructed. For individual species that occurred in two of the three study sites, Shapiro-Wilk test of normality (Shapiro \& Wilk 1965) was used to determine if the distribution of $\mathrm{DBH}$ was normal. Thereafter, $t$-tests were conducted to evaluate if mean DBHs differed significantly. All statistically significant differences were declared at $\mathrm{p}<0.05$.

\section{RESULTS}

Mean tree DBH values for all species were 6.4, 7.6 and $4.6 \mathrm{~cm}$ for Kathonzweni, Kibwezi and Nthangu respectively. Tree species with the highest mean diameters at the three respective sites were Acacia tortilis $(12.3 \mathrm{~cm})$, Adansonia digitata $(148.4 \mathrm{~cm})$ and Faurea Saligna $(10.6 \mathrm{~cm})$ while those with the lowest means were Combretum collinum $(4.8 \mathrm{~cm})$, Solanum incanum $(4.3 \mathrm{~cm})$ and Pachystigma schumannianum $(3.5 \mathrm{~cm})$ (Table 2).

For the individual species that occurred in two of the three sites, mean DBH value for Acacia tortilis at Kathonzweni $(12.34 \pm 1.13 \mathrm{~cm})$ was not significantly different $(p=0.962)$ from that at Kibwezi $(12.25 \pm 1.587 \mathrm{~cm})$. Acacia nilotica had a significantly higher $(\mathrm{p}<0.05)$ mean $\mathrm{DBH}$ at Kathonzweni $(10.50 \pm 0.90 \mathrm{~cm})$ than at Kibwezi $(7.23 \pm 0.41 \mathrm{~cm})$. Likewise, mean DBH for Terminalia brownii was significantly higher $(\mathrm{p}<0.05)$ at Kathonzweni $(10.05 \pm 1.41 \mathrm{~cm})$ than at Nthangu $(5.17 \pm 1.24 \mathrm{~cm})$.

\section{Overall diameter distribution}

DBH ranged from $1.0-22.0,0.3-32.5$ and $1.0-257.3 \mathrm{~cm}$ at Nthangu, Kathonzweni and Kibwezi sites respectively. Majority of the trees occurring at the three sites fell within the lowest diameter classes (Figures 2a-c).

At Nthangu (Figure 2a) and Kibwezi (Figure 2c) forests, the lowest diameter classes had larger number of plants than the second lowest (thus, showing near-perfect inverted J-shaped distributions). Conversely, the number of plants in the lowest diameter class $(1.0-3.9 \mathrm{~cm})$ at Kathonzweni (Figure 2b) was lower than in the second lowest diameter class $(4.0-6.9 \mathrm{~cm})$. From $4.0-6.9 \mathrm{~cm}$ diameter class onwards, the trend was similar to that of the other two sites. The range of diameters at Kibwezi was wider than that at the rest of the sites. 
Table 2 Arithmetic mean diameters of ecologically important tree species at three sites of Makueni county, Kenya

\begin{tabular}{|c|c|c|c|c|c|c|c|}
\hline \multirow[t]{2}{*}{ Study site } & \multirow[t]{2}{*}{ Species } & \multirow[t]{2}{*}{ IVI } & \multicolumn{4}{|c|}{ DBH $(\mathrm{cm})$} & \multirow[t]{2}{*}{$\mathrm{n}$} \\
\hline & & & Mean & Max & Min & Range & \\
\hline \multirow[t]{9}{*}{ Nthangu } & Searsia spp. & 29.1 & 3.81 & 9.0 & 1.5 & 8.0 & 67 \\
\hline & Combretum molle & 23.2 & 8.05 & 22.0 & 1.0 & 21.0 & 21 \\
\hline & Acacia hockii & 18.7 & 5.51 & 13.0 & 2.5 & 10.5 & 24 \\
\hline & Diospyros mespilifor & 18.0 & 5.22 & 21.0 & 2.0 & 19.0 & 32 \\
\hline & Pithosporum viridiflorum & 17.1 & 9.84 & 18.0 & 2.5 & 15.5 & 15 \\
\hline & Terminalia brownii & 12.9 & 5.17 & 18.0 & 4.0 & 14.0 & 17 \\
\hline & Euclea divinorum & 12.6 & 6.94 & 20.0 & 3.0 & 17.0 & 15 \\
\hline & Pachystigma schumann & 11.3 & 3.46 & 6.0 & 1.0 & 5.0 & 26 \\
\hline & Faurea saligna & 8.8 & 10.57 & 21.0 & 4.0 & 17.0 & 7 \\
\hline \multirow[t]{9}{*}{ Kathonzweni } & Combretum collinum & 60.7 & 4.83 & 32.5 & 0.3 & 32.2 & 257 \\
\hline & T. brownii & 34.8 & 10.05 & 20.0 & 3.0 & 17.0 & 14 \\
\hline & Acacia tortilis & 33.8 & 12.34 & 24.0 & 2.5 & 21.5 & 47 \\
\hline & Combretum apiculatum & 25.7 & 7.48 & 20.5 & 2.0 & 18.5 & 65 \\
\hline & Commiphora baluensis & 16.3 & 9.25 & 19.0 & 1.5 & 17.5 & 16 \\
\hline & Commiphora campestris & 15.4 & 8.65 & 18.5 & 3.5 & 15.0 & 27 \\
\hline & Acacia nilotica & 14.8 & 10.50 & 21.0 & 3.5 & 17.5 & 33 \\
\hline & Lannea triphylla & 14.6 & 7.41 & 13.0 & 3.2 & 9.8 & 47 \\
\hline & Sterculia africana & 10.3 & 8.05 & 16.0 & 2.0 & 14.0 & 11 \\
\hline \multirow[t]{9}{*}{ Kibwezi } & Adansonia digitata & 45.7 & 148.4 & 257.3 & 85.0 & 172.3 & 4 \\
\hline & A. tortilis & 33.4 & 12.25 & 33.0 & 1.9 & 31.1 & 205 \\
\hline & Acacia mellifera & 17.4 & 6.95 & 31.0 & 1.5 & 29.5 & 123 \\
\hline & Commiphora africana & 15.0 & 9.84 & 34.0 & 2.0 & 32.0 & 73 \\
\hline & Croton dichogamus & 10.7 & 5.03 & 12.1 & 1.5 & 10.6 & 95 \\
\hline & Delonyx elata & 10.1 & 34.57 & 92.0 & 2.0 & 90.0 & 8 \\
\hline & Acacia elatior & 8.1 & 10.75 & 44.5 & 1.0 & 43.50 & 24 \\
\hline & A. nilotica & 7.8 & 7.23 & 17.0 & 3.5 & 13.5 & 38 \\
\hline & Solanum incanum & 7.7 & 4.33 & 8.6 & 1.3 & 7.3 & 51 \\
\hline
\end{tabular}

\section{Diameter distributions of ecologically important tree species}

Ecologically important tree species at Nthangu forest were: Searsia spp., Combretum molle, A. hockii, Diospyros mespiliformis, Pithosporum viridiflorum, T. brownii, Euclea divinorum, Pachystigma schumannianum and F. saligna (Table 2). At this site, majority of the species followed the inverse J-shaped DBH distribution trend in which the majority of the trees measured fell within the lower diameter classes $(1.0-10.0 \mathrm{~cm})$. The rest of the species such as C. molle and P. viridiflorum did not show consistent trends (Figure 3a).
Ecologically important tree species at Kathonzweni forest were C. collinum, T. brownii, A. tortilis, C. apiculatum, Commiphora baluensis, Commiphora campestris, A. nilotica, Lannea triphylla and Sterculia africana. Only S. africana showed a typical inverse J-shaped trend with the highest number of individuals in the lowest diameter class, while all the other species had a lower number of individuals in the lowest diameter class $(1.0-3.9 \mathrm{~cm})$ than in the second lowest class (Figure 3b).

Ecologically important tree species at Kibwezi forest were: A. digitata, A. tortilis, Acacia mellifera, C. africana, Croton dichogamus, Delonyx 

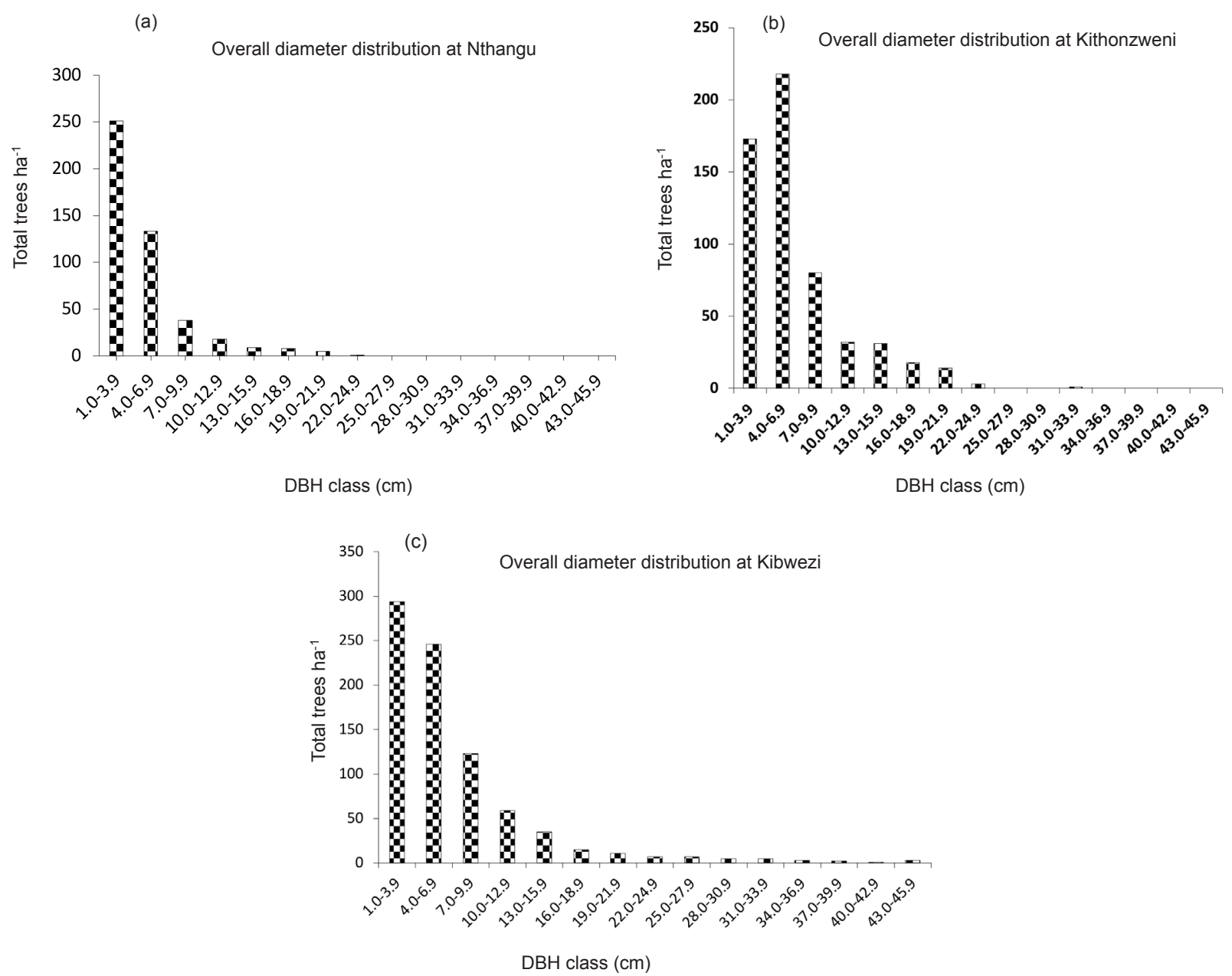

Figure 2 Overall diameter distribution of tree species occurring at (a) Nthangu, (b) Kathonzweni and (c) Kibwezi, Makueni County

elata, Acacia elatior, A. nilotica and S. incanum. Most of the species comprising this dominant group belonged to the genus Acacia that also contributed the largest number of trees per hectare. Commiphora africana, A. elatior and $S$. incanum had inverse J-shaped DBH distributions from the lowest diameter classes $(1.0-3.9 \mathrm{~cm})$, while the same applied to the rest from the second or third lowest diameter classes. The acacias and C. africana had their members represented in most of the diameter classes.

\section{DISCUSSION}

Tree species at Nthangu, Kathonzweni and Kibwezi forests had overall mean DBHs of 4.6, 6.4 and $7.6 \mathrm{~cm}$ respectively. The small DBH sizes may be attributed to the long-term effects of low and poorly distributed rainfall in the area (Coughenour \& Ellis 1993). It was suggested that rainfall amounts over much of the study area were too low to support large trees, which only occurred in association with water concentration zones such as riparian zones and micro-drainages.

Mean DBHs obtained for the three sites indicated that trees at the Kibwezi site were larger than those at Kathonzweni and Nthangu sites. This was not consistent with information reported in literature in which sites characterised by higher rainfall regimes have larger trees (Coughenour \& Ellis 1993, Myers \& Neales 1984). It is suggested that this may partly be a result of the clear-felling incident that occurred at Nthangu forest in 1996 and affected natural vegetation from the more productive parts of the forest. As re-planting was done using exotic species, the vegetation survey was conducted on a less productive section with smaller size indigenous natural vegetation.

On the other hand, trees at Kibwezi forest were large possibly because of the protection provided by the university against any encroachment. Trees at Kathonzweni were exposed to adverse human interferences, and did not benefit from the effects of higher rainfall as Nthangu or protection 

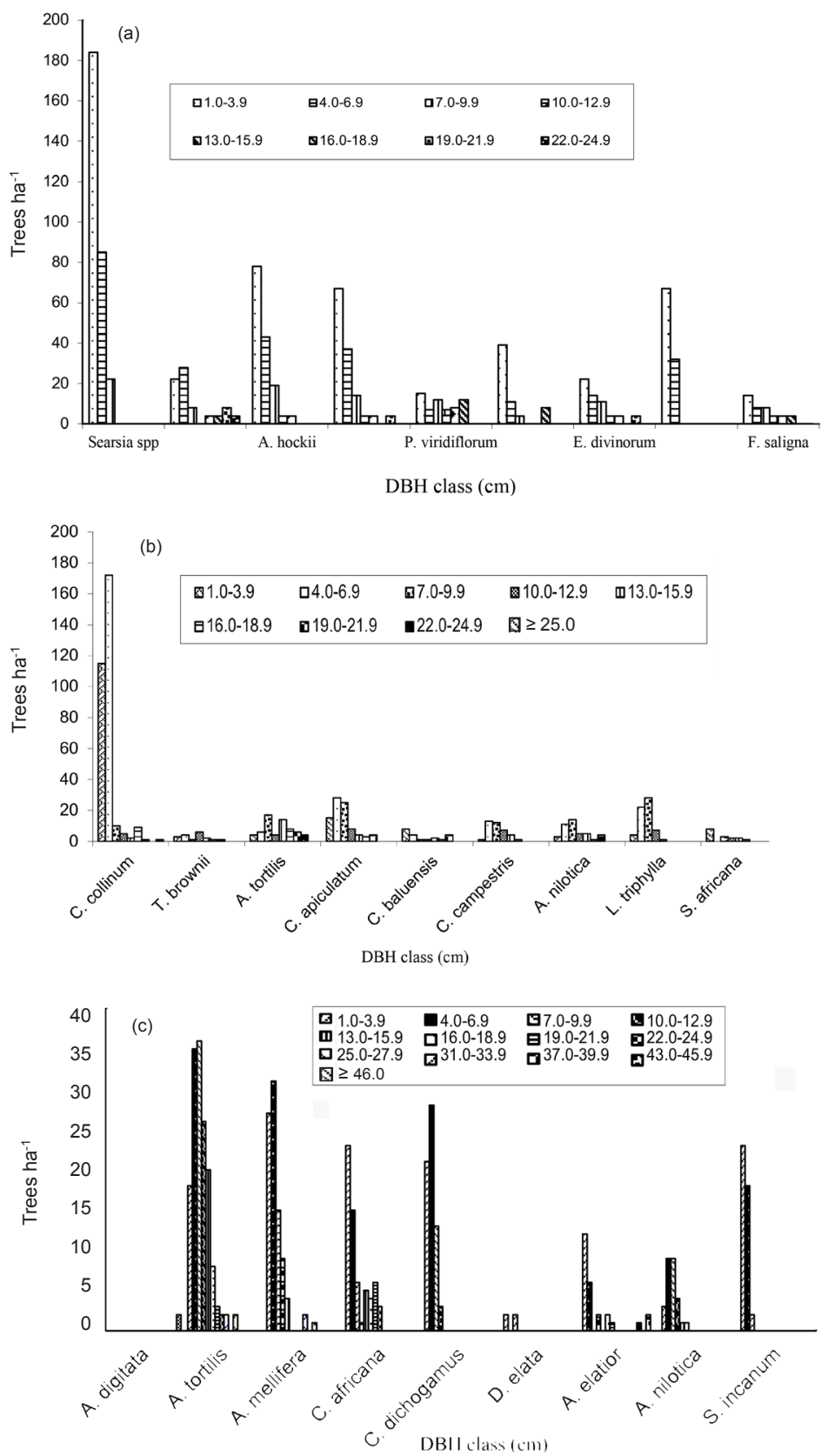

Figure 3 Diameter distribution of ecologically important tree species at (a) Nthangu, (b) Kathonzweni and (c) Kibwezi

from encroachment as Kibwezi. Hence, they were generally small in size. According to Ward and Micin (2006) and Gazal et al. (2006), plants growing in higher rainfall areas, and hence with better access to ground water, are larger. Alteration of natural ecosystems by human influences is a common phenomenon worldwide.

Size distributions of tree species in this study showed that the majority of individuals were within the small diameter classes. At Nthangu forest and Kibwezi, the DBH frequency bar graphs were high at the smallest diameter classes and declined smoothly to maximum diameters of 25.0 and over $46.0 \mathrm{~cm}$ respectively. This is consistent with results of other studies in which most tree populations consist of relatively few large individuals and many small ones, and the few large individuals account for most of the population biomass (Weiner 1985, Benjamin \& Hardwick 1986). Similar observations were made in the Miombo ecosystem of western Tanzania where four different land management areas had size class distributions with greater numbers of juvenile trees $(2-10 \mathrm{~cm} \mathrm{DBH})$ than adults (Banda et al. 2006). Such trends are desirable because J-inverse DBH distribution indicates 
regenerating, sustainable and stable populations that have potential to impact positively on the lives of future generations (Nduwayezu et al. 2015).

Overall DBH distribution at Kathonzweni showed trends in which there were few individuals in the lowest size classes compared with the middle classes. Juma (2002) observed similar distributions on Melia volkensii that showed age and size class distribution with high frequency of mature trees, and no seedlings. Such size distribution implies unstable plant population structures (Rocky \& Mligo 2012) and suggests either that climatic conditions for establishment of at least a section of the population have been unfavourable, or that there have been recent increases in over-exploitation due to unchecked human interference (Robi \& Edris 2017) and livestock browsing. In the case of Kathonzweni in this study, the latter may be possible because the site was not under protection by any lawful authority, and was subject to cases of encroachment. The local people usually cut trees for firewood, charcoal, poles and browse, while livestock species such as cattle, goats and donkeys roam about mostly unrestricted. Levitt (1972) attributed a typical age and size-class distribution to browsing effect of goats, giraffe, orix, lesser kudu, and on farms, lopping or pruning for fodder. Weiner (1985) suggests that the reduced number or absence of small individuals in a population may be attributed to density-dependent mortality of the smallest plants, and that within a population, size is correlated with fitness. Such distribution is risky as it indicates a situation where populations decline in size and, in the absence of urgent remedial measures, disappear with time.

This study indicates that it is not enough to recommend tree species for rehabilitation in semi-arid rangelands merely based on their ability to grow and adapt to respective sites. Their stability and sustainability should be considered. Tree species with near-perfect inverted J-shaped size distributions in which small diameter classes have large numbers of individuals and large diameter classes have small numbers of individuals are not only adapted but are also stable and can propagate sustainably in respective sites. They show that there would be sufficient trees in the lower diameter classes to replace those in the upper DBH classes when they mature.

\section{CONCLUSIONS}

Based on results of this study, adapted tree species at Nthangu forest that showed nearperfect inverse J-shaped DBH distribution, thus indicating regenerating, sustainable and stable populations, were Searsia spp., A. hockii and Diospyros mespiliformis. At Kathonzweni, they were C. collinum, C. apiculatum and A. tortilis, while at Kibwezi, they were A. tortilis, $A$. mellifera and C. africana. There was, however, evidence of interferences on the natural state of vegetation by humans and livestock. Hence, the trends may not be as clear as those that would have been observed under undisturbed natural conditions.

\section{ACKNOWLEDGEMENTS}

Financial support for this study was received from the German Academic Exchange Service, the Kenya Forestry Research Institute (KEFRI) and the Belgian Technical Cooperation (BTC) through the KEFRI/BTC Agroforestry for Integrated Development in Semi-arid Areas of Kenya (ARIDSAK) Project. Musya D and Kivilu J helped in the identification of indigenous trees by their local names. Oeba $\mathrm{V}$ and Okoth $\mathrm{S}$ assisted in the statistical analyses of data. Ngugi J provided GIS support. Kamondo B helped in editing the manuscript. These institutions and individuals are gratefully acknowledged.

\section{REFERENCES}

Anonymous. 2006. District Land Cover Atlas: Aggregated Land Cover Maps and Statistics for Kenya. Technical Report No. 160. The Department of Resource Surveys and Remote Sensing, Nairobi.

Anonymous. 1997. Makueni District Development Plan 19972001. Ministry of Finance and Planning, Nairobi.

Anonymous. 2010. Guiding Principles on Use of Native Plant Species in the Public Works Projects. Greening, Landscape and Tree Management Section Development Bureau, Tamar. http://www: greening. gov.hk/. (Accessed on 23 June 2013)

Banda T, SchWARtz MW \& CARo T. 2006. Woody vegetation structure and composition along a protection gradient in a miombo ecosystem of western Tanzania. Forest Ecology and Management 230: 179-185. doi: 10.1016/j.foreco.2006.04.032.

Beentje H. 1994. Kenya Trees, Shrubs and Lianas. National Museums of Kenya, Nairobi.

BENJAMIN LR \& HARDWICK RC. 1986. Sources of variation and measures of variability in even-aged stands of plants. Annals of Botany 58: 757-778. 
Braun H, Albrecht J \& Kamondo BM. 1993. The Forest Seed Zones of Kenya. GTZ Forestry Seed Centre, Muguga.

Coughenour MB \& Ellis JE. 1993. Landscape and climatic control of woody vegetation in a dry tropical ecosystem: Turkana district, Kenya. Journal of Biogeography 20: 383-398.

Dale IR \& Greenway PJ. 1961. Kenya Trees and Shrubs. Buchanan's Kenya Estate Ltd., Nairobi and Hatchards, London.

Derbel S \& Chaieb M. 2013. Growth establishment and phenology of four woody Saharan species. African Journal of Ecology 51: 307-318. https://doi. org/10.1111/aje.12036.

EckHardt HC, Van Wilgen BW \& Biggs HC. 2000. Trends in woody vegetation cover in the Kruger National Park, South Africa, between 1940 and 1998. African Journal of Ecology 38: 108-115. https://doi.org/10.1046/ j.1365-2028.2000.00217.x.

Ensor J \& Berger R. 2009. Understanding Climate Change Adaptation: Lessons From Community-Based Approaches. Practical action publishers Ltd., Warwickshire.

Gandiwa E. 2011. Effects of repeated burning on woody vegetation structure and Composition in a semi-arid southern African savanna. International Journal of Environmental Sciences 2: 458-471.

GazaL RM, Scott RL, Goodrich DC \& Williams DG. 2006. Controls on transpiration in a semi-arid riparian cottonwood forest. Agricultural and Forest Meteorology 137: 56-67. doi:10.1016/j.agrformet.2006.03.002.

Gonzalez P, Tucker CJ \& SYH. 2012. Tree density and species decline in the African Sahel attributable to climate. Journal of Arid Environments 78: 55-64. doi:10.1016/j. jaridenv.2011.11.001.

JAETzOLD R. 1983. Explanation of the evaluation of the natural potential: methods of the agro-ecological zonation. Pp 9-19 in Jaetzold R \& Schmidt H (eds) Farm Management Handbook for Kenya Volume II: Natural conditions and Farm Management Information, Part B: Central Kenya (Rift Valley and Central Provinces). Ministry of Agriculture GTZ, Nairobi.

JumA P. 2002. Optimization of Melia volkensii (GURKE) as an alternative MPTs in dryland agroforestry systems for soil and water conservation. BSc project report, Moi University, Eldoret.

Kefri (Kenya Forestry Research Institute). 1990. A Guide to Tree Planting in Kenya. KEFRI, Nairobi.

KIGOMo BN. 2003. Restoration of woody vegetation for better livelihoods: the Ukambani and Maasai land in Kenya. Paper presented at the XII World Forestry Congress, 21-28 September, 2003, Quebec City.

LAmbrecht H. 1989. Silviculture in the Tropics: Tropical Forest Ecosystems and Their Tree Species: Possibilities and Methods for Their Long-Term Utilization. Deutsche Gesellschaft für Technische Zusammenarbeit (GTZ), Eschborn.

Levitt J. 1972. Responses of Plants to Environmental Stress. Academic press, New York. doi: 10.1126/ science.177.4051.786.

Maundu P \& Tengnas B. 2005. Useful Trees and Shrubs for Kenya. Technical Handbook No. 35. World Agroforestry Centre-Eastern and Central Africa Regional Programme (ICRAF-ECA), Nairobi.

Mengich EK, Too DK, Macharia JM \& Mitloehner R. 2013. Composition and distribution of indigenous trees and shrubs as possible criteria for indicating adapted species in semi-arid rangelands. African Journal of Ecology 53: 3-15.
Milimo PB, Dick JMCP \& Munro RC. 1994. Domestication of trees in semi-arid East Africa: the current situation. In Leakey RRB \& Newton AC (eds) Tropical Trees: The Potential for Domestication and the Rebuilding of Forest Resources. HMSO, London.

Misra R. 1968. Ecology Workbook. Oxford IBH Publishing Company, Calcutta.

Mulizane M, Katsvanga CAT, Nyakudya IW \& Mupangwa JF. 2005. The growth performance of exotic and indigenous tree species in rehabilitating active gold mine tailings dump at Shamva mine in Zimbabwe. Journal of Applied Sciences E Environmental Management 9: 57-59. http://dx.doi.org/10.4314/ jasem.v9i2.17292.

Musembi DK. 1986. The seasonal climate of rangelands. Pp 183-188 in Hansen RM et al. (eds) Range Development and Research in Kenya-Proceedings of a Conference. 1-5 April 1986, Njoro.

Myers BA \& Neales TF. 1984. Seasonal changes in the water relations of Eucalyptus behriana F. Muell. and E. microcarpa (Maiden) Maiden in the field. Australian Journal of Botany 32: 495-510. https:/ / doi. org/10.1071/BT9840495.

Nounayezu JB, Mafoko GJ, Mojeremane W, Mhaladi LO. 2015. Vanishing multipurpose indigenous trees in Chobe and Kasane Forest Reserves of Botswana. Resources and Environment 5: 167-172. doi: 10.5923/j. re. 20150505.05

Oba G, Nordal I, Stenseth NC, Stave J, BJora C, Muthondeki J \& BII W. 2001. Growth performance of exotic and indigenous tree species in saline soils in Turkana, Kenya. Journal of Arid Environments 47: 499-511. https://doi.org/10.1006/jare.2000.0734.

Reubens B, Moeremans C, Poesen J et al. 2011. Tree species selection for land rehabilitation in Ethiopia: from fragmented knowledge to integrated multi-criteria decision approach. Agroforestry Systems 82: 303-330. doi: 10.1007/s10457-011-9381-8.

RoBI MK \& EDRIS EM. 2017. Distribution, abundance and population status of four indigenous threatened tree species in the Arba Minch Natural Forest, Southern Ethiopia. International Journal of Natural Research Ecology E Management 2: 1-8. doi: 10.11648/j. ijnrem.20170201.11.

Rocky J \& Mligo C. 2012. Regeneration pattern and size class distribution of indigenous woody species in exotic plantation in Pugu forest reserve, Tanzania. International Journal of Biodiversity and Conservation 4: 1-14. doi: 10.5897/IJBC11.198.

SHAPIRO SS \& WILK MB. 1965. An analysis of variance test for normality (complete samples). Biometrika 52: 591611. https://doi.org/10.1093/biomet/52.3-4.591.

SHIVER BD \& Borders BE. 1996. Sampling Techniques for Forest Resource Inventory. John Wiley and Sons, New York.

Sombroek WG, Braun HMH \& Van Der Pouw BJA. 1982. Exploratory Soil Map and AgroClimatic Zone Map of Kenya, 1980. Scale: 1:1'000'000. Exploratory Soil Survey Report No. E1. National Agricultural Laboratories, Nairobi.

WARD PR \& MicIN SF. 2006. The capacity of dryland Lucerne for ground water uptake. Australian Journal of Agricultural Research 57: 483-487. doi:10.1071/ar05311.

WEINER J. 1985. Size hierarchies in experimental populations of annual plants. Ecology 66: 743-752. https://doi. org/10.2307/1940535. 